\title{
Rancang Bangun Aplikasi Absensi Perkuliahan Mahasiswa dengan Pengenalan Wajah
}

\author{
Muhammad Yusuf, R. V. Hari Ginardi, dan Adhatus Solichah A. \\ Jurusan Teknik Informatika, Fakultas Teknologi Informasi, Institut Teknologi Sepuluh Nopember (ITS) \\ Jl. Arief Rahman Hakim, Surabaya 60111 Indonesia \\ e-mail: hari@its.ac.id
}

\begin{abstract}
Abstrak-Proses absensi yang dilakukan secara manual dinilai kurang efektif karena terbukanya kesempatan melakukan kecurangan. Selain itu, proses rekapitulasi manual membutuhkan waktu yang lama. Sistem absensi dengan teknologi dapat diterapkan untuk membantu proses absensi dan rekapitulasi yang efektif. Pada tugas akhir ini, teknologi yang digunakan adalah sistem pengenalan wajah. Pembuatan aplikasi absensi dengan pengenalan wajah ini menggunakan metode Eigenface untuk melakukan proses pengenalan wajah. Sedangkan data-data yang dibutuhkan sistem adalah data mata kuliah, dosen, jadwal, kelas, mahasiswa, dan dataset foto wajah yang disimpan dalam sistem manajemen relasional basis data. Hasil dari aplikasi yang dibangun yaitu dapat mengelola data-data pada sistem, serta melakukan pencatatan dan perekapan data absensi. Proses absensi mahasiswa berhasil dilakukan pada kondisi pencahayaan yang bagus dan resolusi yang sama dengan kondisi foto wajah yang disimpan dalam basis data.
\end{abstract}

Kata Kunci-Absensi, Mahasiswa, Pengenalan Wajah, Eigenface, Sistem Manajemen Basis Data Relasional

\section{PENDAHULUAN}

$\mathrm{S}$ ISTEM absensi adalah hal yang penting dalam sebuah perkuliahan sebagai pencatat kehadiran mahasiswa. Di kampus Institut Teknologi Sepuluh Nopember (ITS) Surabaya, kehadiran menentukan seorang mahasiswa berhak atau tidak untuk mengikuti Evaluasi Akhir Semester (EAS) dengan persentase $80 \%$ dari 16 pertemuan pada satu semester. Selama ini di ITS khususnya di jurusan Teknik Informatika, sistem absensi masih dilakukan secara manual dengan menandatangani lembar kertas absensi. Hal itu tentu kurang efektif karena terbukanya kesempatan untuk melakukan kecurangan. Selain itu, rekapitulasi oleh Tata Usaha (TU) juga dilakukan dengan cara manual yang membutuhkan waktu lama karena harus memasukkan banyak data.

Dengan semakin berkembangnya bidang teknologi, saat ini telah banyak dibangun sistem absensi dengan pengenalan pola yang mengenali ciri-ciri khusus fisik seseorang diantaranya pengenalan wajah, pengenalan iris, dan pengenalan sidik jari. Pencatatan absensi menggunakan pengenalan pola yang mengenali ciri-ciri fisik seseorang untuk perkuliahan mahasiswa sebelumnya pernah diterapkan di jurusan Sistem Informasi ITS yaitu dengan pengenalan sidik jari, akan tetapi sekarang sudah tidak berjalan dan alat fingerprint hanya terpasang di tiap kelas. Dengan memanfaatkan pola ciri-ciri khusus fisik pula tugas akhir ini akan mengenali seseorang, yaitu dengan pengenalan wajah.

Sistem yang dibangun memanfaatkan web camera (webcam) pada komputer untuk melakukan absensi. Tujuan dikembangkannya sistem ini adalah untuk memberikan solusi yang efektif dalam pencatatan dan perekapan absensi perkuliahan.

\section{TINJAUAN PUSTAKA}

\section{A. Pengenalan Wajah}

Pengenalan wajah merupakan salah satu pendekatan pengenalan pola untuk keperluan identifikasi wajah seseorang dengan pendekatan biometrik. Suatu biometrik bersifat unik sehingga dapat digunakan untuk mengenali identitas seseorang. Proses pengenalan biometrik dapat dibagi menjadi dua karakteristik, yaitu secara fisik dan secara perilaku. Biometrik fisik berasal dari pengukuran dan data yang ada langsung dari bagian manusia misalnya pengenalan sidik jari, pengenalan wajah, iris, retina, dan tangan. Sedangkan biometrik perilaku berasal dari pengukuran dan data yang berasal dari tindakan seperti suara, tanda tangan, dan keystrokes. Sistem biometrik mengacu pada terintegrasinya antara perangkat keras dan perangkat lunak untuk melakukan proses identifikasi dan verifikasi.

Sistem pengenalan wajah adalah sebuah aplikasi komputer yang mampu mengidentifikasi atau mengenali wajah seseorang dari gambar digital atau video. Salah satu cara yang digunakan dalam pengenalan wajah yaitu dengan membandingkan wajah dari gambar yang dipilih atau video dengan basis data wajah.

Pengenalan wajah manusia telah menarik banyak para peneliti. Sebuah sistem pengenalan wajah bisa ditemukan pada banyak aplikasi dari berbagai bidang seperti Interaksi Manusia dan Komputer (IMK), sistem keamanan, dan lain-lain [1].

\section{B. Emgu $C V$}

Emgu CV adalah sebuah jembatan lintas platform .Net untuk menghubungkan ke library pengolahan gambar Open CV. Emgu CV memungkinkan untuk memanggil fungsi Open $\mathrm{CV}$ ke berbagai bahasa .Net seperti C\#, VB, VC++, IronPython dan lain-lain, yang dapat di-compile pada Visual Studio, Xamarin Studio, dan Unity, serta dapat dijalankan pada perangkat Windows, Linux, Mac OS X, iOS, Android, dan Windows Phone [2]. 


\section{Metode Eigenface}

Eigenface adalah nama yang diberikan untuk satu set eigenvector ketika digunakan dalam pengenalan wajah pada bidang visi komputer. Dalam istilah Layman, Eigenface adalah sekumpulan standardized face ingredient dari analisis statistik dari banyak gambar wajah [3]. Pendekatan Eigenfaces untuk pengenalan wajah dikembangkan oleh Sirovich dan Kirby (1987) dan digunakan oleh Matthew Turk dan Alex Pentland pada klasifikasi wajah [4]. Selain merancang sistem untuk pengenalan wajah, Matthew Turk dan Alex Pentland juga menunjukkan cara menghitung eigenvector untuk melakukan eigendecomposition pada sebagian besar gambar wajah. Eigenvector berasal dari kovarian matriks distribusi probabilitas pada ruang vektor dari gambar wajah [5]. Dataset wajah yang digunakan harus diambil dalam kondisi pencahayaan dan resolusi yang sama dengan saat melakukan pengenalan wajah baru.

Algoritma pengenalan wajah dengan metode Eigenface dilakukan melalui beberapa tahapan [6], yaitu:

1. Menyusun Flatvector Matriks Citra

2. Menghitung Nilai Tengah atau Mean ( $\Psi$ )

3. Menghitung Selisih antara Training Image dengan Nilai

Tengah atau Mean ( $\Psi$ )

4. Menghitung Nilai Matriks Kovarian

5. Menghitung Nilai Eigenvalue dan Eigenvector

6. Mencari Nilai Eigenface

7. Proses Identifikasi

\section{Penelitian Terkait}

Beberapa penilitian terkait dengan tugas akhir ini diantaranya penelitian yang dilakukan oleh Priyanka Wagh, Roshani Thakare, Jagruti Chaudhari, dan Shweta Patil dalam jurnal yang berjudul Attendance System based on Face Recognition using Eigenface and PCA Algorithm. Hasil penelitian menunjukkan bahwa sistem kehadiran yang otomatis dapat dibuktikan sebagai sistem yang efisien untuk pencatatan kehadiran mahasiswa. Dengan menggunakan sistem ini, kemungkinan kecurangan dapat dikurangi [7].

Muhammad Rizki Muliawan, Beni Irawan, dan Yulrio Brianorman dalam jurnal yang berjudul Implementasi Pengenalan Wajah dengan Metode Eigenface pada Sistem Absensi. Penelitian ini mendapatkan hasil yang berbeda-beda antara wajah satu dengan wajah yang lainnya, pada saat basis data berisi 10 data wajah, hasil rata-rata persentase kecocokan mencapai $88 \%$, sedangkan pada saat basis data berjumlah 20 data wajah, hasil rata-rata persentase kecocokan mencapai $52 \%$. Penyebab dari perbedaan hasil tersebut adalah faktor pencahayaan, jarak, bentuk wajah, serta jumlah data yang tersedia [6].

\section{ANALISIS DAN PERANCANGAN}

\section{A. Deskripsi Umum Sistem}

Aplikasi yang dibuat dalam tugas akhir ini merupakan aplikasi absensi perkuliahan mahasiswa dengan pengenalan wajah. Aplikasi perkuliahan mahasiswa ini merupakan aplikasi berbasis desktop. Aplikasi ini berupa prototipe dan tidak terintegrasi dengan sistem informasi yang ada di ITS. Aplikasi ini dibangun menggunakan metode Eigenface yang merupakan algoritma dari library Open CV yang dipanggil dalam bahasa pemrograman $C \#$ dengan menggunakan library Emgu $\mathrm{CV}$. Metode ini nantinya digunakan untuk mengenali wajah mahasiswa saat melakukan absensi mahasiswa pada suatu perkuliahan. Semua data yang ada pada aplikasi disimpan dalam relasional manajemen basis data MySQL. Data-data yang dibutuhkan pada sistem dikelola oleh pengguna administrator dan tata usaha. Semua menu yang bisa diakses oleh pengguna tata usaha juga dapat diakses oleh pengguna administrator. Perbedaan antara pengguna administrator dan tata usaha terletak pada menu Tata Usaha, dimana administrator bisa mengelola data-data dari tata usaha.

Proses absensi diawali dengan dosen login ke sistem absensi, kemudian mengisi detail materi pada berita acara perkuliahan suatu mata kuliah dan menekan tombol "Mulai Absensi". Proses absensi dilakukan dengan menggunakan webcam pada komputer. Aplikasi akan mendeteksi dan mengenali wajah mahasiswa jika dataset wajah yang ada di basis data memiliki pencahayaan dan resolusi yang sama pada saat melakukan absensi. Ketika wajah dikenali oleh aplikasi, maka aplikasi akan mengkonfirmasi apakah benar wajah yang dikenali oleh sistem adalah wajah mahasiswa yang bersangkutan. Jika mahasiswa mengkonfirmasi benar, maka sistem akan mencatat kehadiran mahasiswa dan menyimpannya ke basis data.

\section{B. Identifikasi Pengguna}

Identifikasi pengguna mendifinisikan entitas-entitas yang terlibat dan berinteraksi langsung dengan sistem. Berdasarkan deskripsi umum sistem yang telah dijelaskan pada bagian sebelumnya, maka pengguna yang akan menggunakan aplikasi ini ada empat, yaitu:

1. Administrator

Administrator merupakan pengguna yang bertanggungjawab terkait dengan data tata usaha, dosen, mahasiswa, mata kuliah, kelas, dan jadwal perkuliahan.

2. Tata usaha

Tata Usaha merupakan pengguna yang bertanggungjawab dalam terkait dengan data dosen, mahasiswa, mata kuliah, kelas, dan jadwal perkuliahan

3. Dosen

Dosen merupakan pengguna yang mengatur fitur pada saat perkuliahan, seperti pengisian berita acara perkuliahan dan mengaktifkan fitur absensi pada groupBox Absen yang digunakan mahasiswa untuk melakukan absensi perkuliahan.

4. Mahasiswa

Mahasiswa merupakan pengguna yang hanya memiliki akses untuk melakukan dan melihat absensi.

\section{Perancangan Arsitektur}

Arsitektur aplikasi dapat dilihat pada Gambar 1. Berikut penjelasan arsitektur sistem yang terdapat pada Gambar 1 .

1. Administrator atau tata usaha mengelola data-data yang dibutuhkan sistem.

2. Administrator atau tata usaha mendapatkan data rekapitulasi kehadiran, file ekstraksi data kehadiran, dan data yang dikelola. 
3. Dosen mengisi berita acara pada suatu perkuliahan.

4. Setelah dosen mengisi berita acara, mahasiswa memulai absensi dengan menghadapkan wajah ke depan komputer sehingga webcam dapat menangkap wajah mahasiswa.

Ketika aplikasi mengenali wajah mahasiswa maka aplikasi akan memberikan umpan balik berupa konfirmasi apakah benar data yang dikenali oleh sistem adalah mahasiswa yang bersangkutan. Jika tidak maka aplikasi akan kembali menangkap wajah mahasiswa.
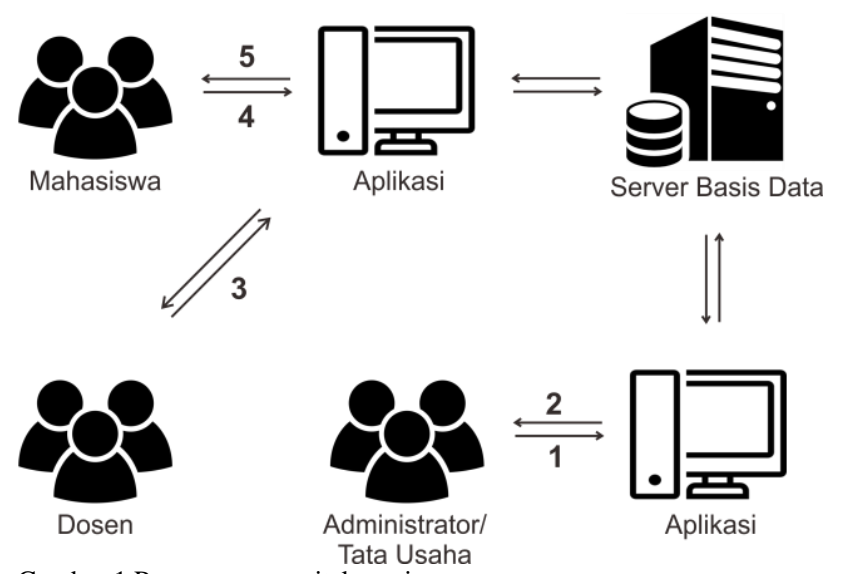

Gambar 1 Perancangan arsitektur sistem

\section{Proses Masukan Data Wajah}

Proses masukan data wajah pada sistem dapat dilihat pada Gambar 2. Pada proses ini, pengguna pertama memilih metode masukan, yaitu dari file foto yang sudah ada atau secara langsung melalui webcam. Kemudian akan ditampilkan pada ImageBox Webcam. Sistem akan mendeteksi wajah dengan metode Haarcascade dari library Emgu CV. Wajah yang dideteksi adalah wajah yang menghadap ke depan, pada pencahayaan yang baik, dan wajah yang tidak terhalangi oleh kacamata, masker, ataupun objek lainnya. Kemudian pengguna meng-capture wajah yang dideteksi dan sistem akan menampilkan wajah hasil capture. Setelah itu, data wajah akan disimpan pada basis data.

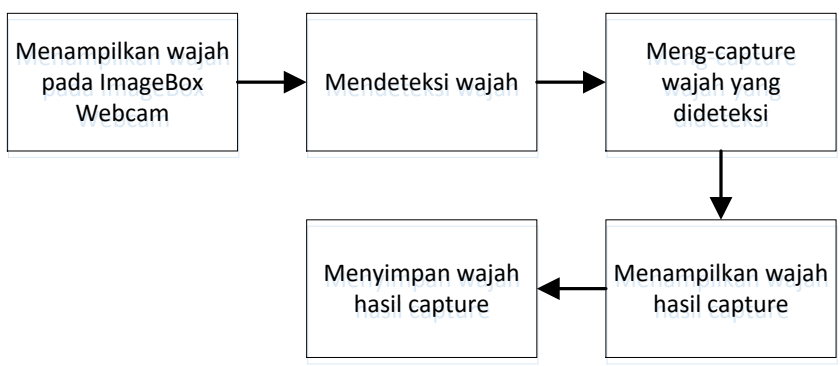

Gambar 2 Proses masukan data wajah

\section{E. Perancangan Basis Data}

Basis data yang dibangun pada aplikasi ini menggunakan sistem manajemen basis data relasional MySQL. Data-data yang disimpan dalam MySQL diantaranya data absensi mahasiswa, data mata kuliah, data jadwal perkuliahan, data mahasiswa, data foto mahasiswa, data mahasiswa per kelas, data dosen, serta data login yang digunakan untuk administrator dan tata usaha. Perancangan basis data dimodelkan dalam diagram model konsep basis data atau Conceptual Data Model (CDM) yang dapat dilihat pada Gambar 3.
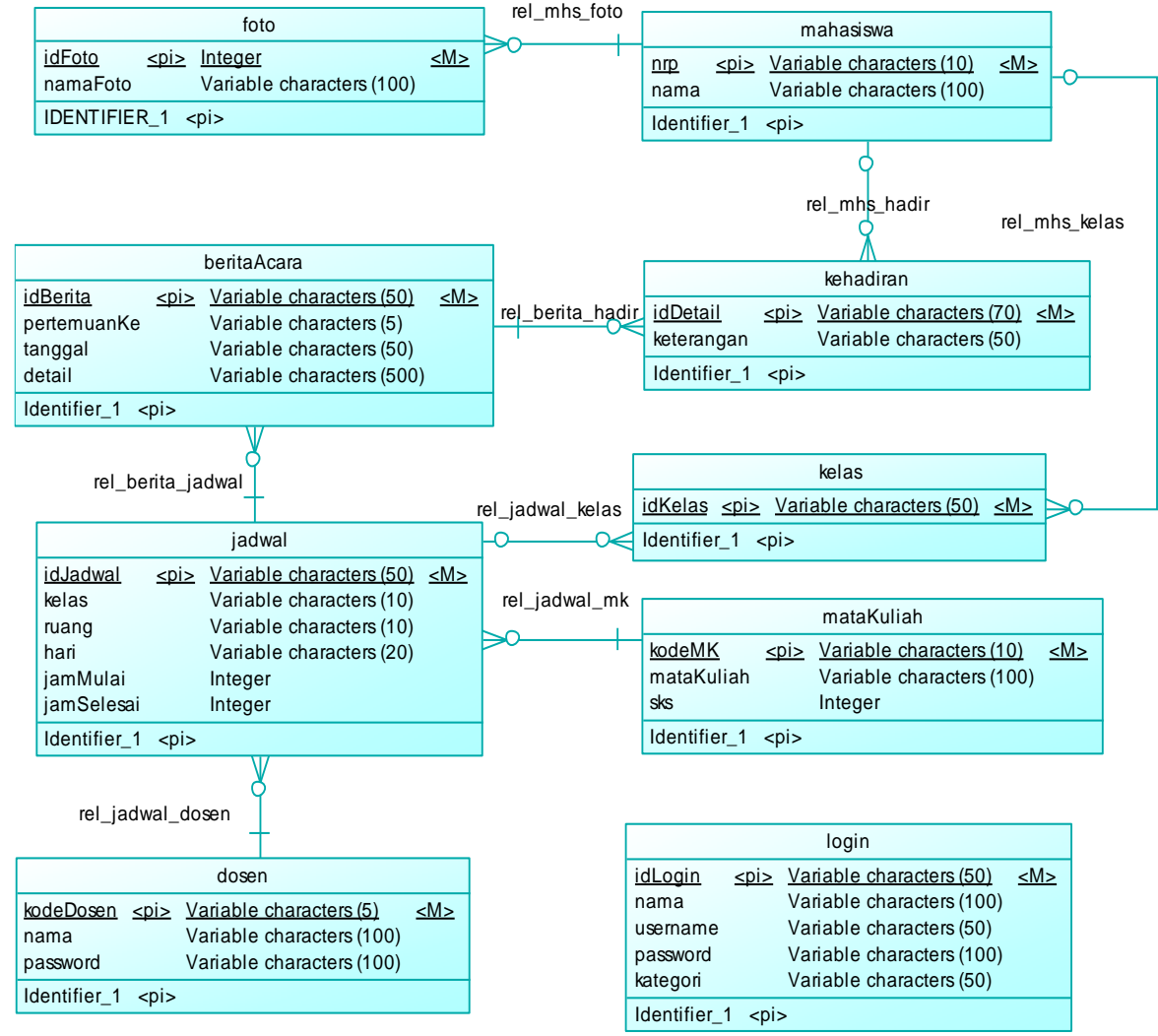

Gambar 3 CDM aplikasi absensi perkuliahan 


\section{IMPLEMENTASI}

Aplikasi ini dibangun dengan basis desktop, menggunakan bahasa pemrograman $\mathrm{C \#}$, library Emgu $\mathrm{CV}$, dan sistem manajemen basis data relasional MySQL. Library Emgu CV digunakan sebagai tools untuk mengimplementasikan metode Eigenface yang digunakan pada proses deteksi dan pengenalan wajah mahasiswa untuk mencatat status kehadiran pada suatu perkuliahan. Dan sistem manajemen basis data relasional MySQL digunakan sebagai server basis data untuk menyimpan semua data pada aplikasi yang berisi tabel login, mahasiswa, foto, dosen, matakuliah, jadwal, kelas, beritaacara, dan kehadiran.

Dalam membangun aplikasi perangkat keras yang digunakan adalah komputer laptop. Spesifikasi dari perangkat tersebut adalah prosesor Inter(R) Core(TM) i3-3217U CPU @ 1.80GHz dan RAM 4.00 GB.

\section{PENGUJIAN DAN EVALUASI}

Dalam melakukan pengujian pada aplikasi dilakukan pada lingkungan dan alat kakas komputer laptop dengan spesifikasi prosesor Inter(R) Core(TM) i3-3217U CPU @1.80GHz, sistem operasi Windows 10 Home Single Language 64-bit, ukuran layar 1280 x 720 pixels, dan RAM 4.00 GB.

Pengujian yang dilakukan adalah pengujian kebutuhan fungsionalitas. Pengujian fungsionalitas menggunakan metode kotak hitam (black box). Metode ini menekankan pada kesesuaian hasil keluaran sistem.

Pada saat pengujian melakukan absensi, mahasiswa diharuskan telah berada pada halaman Absensi. Kemudian mahasiswa menekan tombol Aktifkan dan sistem akan mengaktifkan fitur webcam komputer. Setelah itu, sistem akan mendeteksi dan mengenali wajah mahasiswa dan memberikan konfirmasi apakah benar mahasiswa yang sedang melakukan absensi adalah mahasiswa yang dikenali sistem. Setelah mahasiswa memberikan konfirmasi benar, maka sistem akan mencatat data kehadiran mahasiswa pada kelas dan pertemuan tersebut dan menampilkan keterangan bahwa mahasiswa telah melakukan absensi seperti pada Gambar 4.

Pada proses melihat absensi, pengguna diharuskan telah berada pada halaman Beranda. Data kelas berdasarkan ID Jadwal yang bisa dipilih oleh administrator atau tata usaha. Kemudian administrator atau tata usaha menekan tombol Pilih dan sistem akan menampilkan data absensi perkuliahan mahasiswa pada suatu kelas berdasarkan ID Jadwal yang dipilih seperti pada Gambar 5.

Administrator atau tata usaha menekan tombol Ekstrak File. Kemudan memilih direktori File Explorer untuk menyimpan file. Kemudian akan muncul pesan bahwa data absensi berhasil diekstrak. Hasil ekstraksi file dapat dilihat pada Gambar 6.

Dalam pengujian melakukan absensi dilakukan kepada mahasiswa dengan dataset wajah yang telah disimpan dalam basis data. Contoh dataset yang berhasil dikenali oleh sistem dapat dilihat pada Gambar 7.

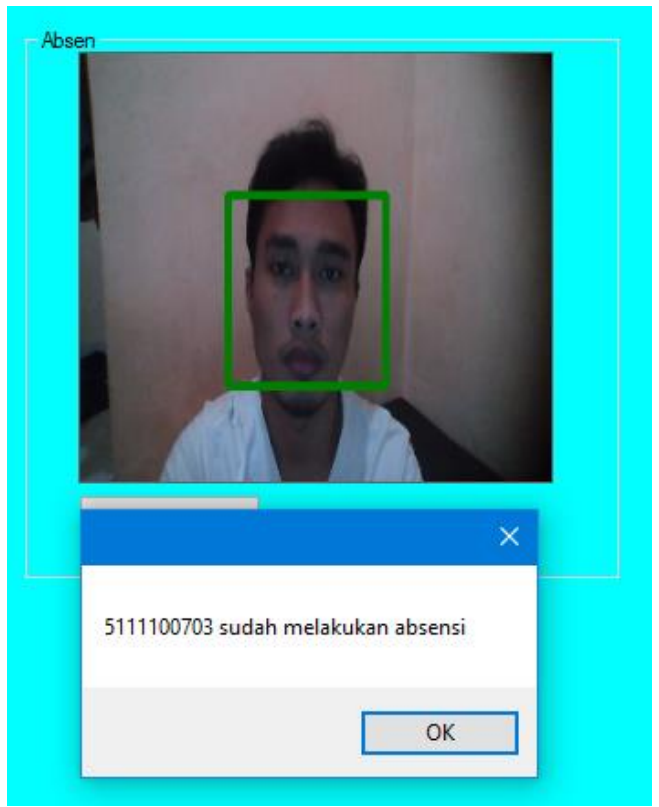

Gambar 4 Sistem berhasil mengenali data wajah

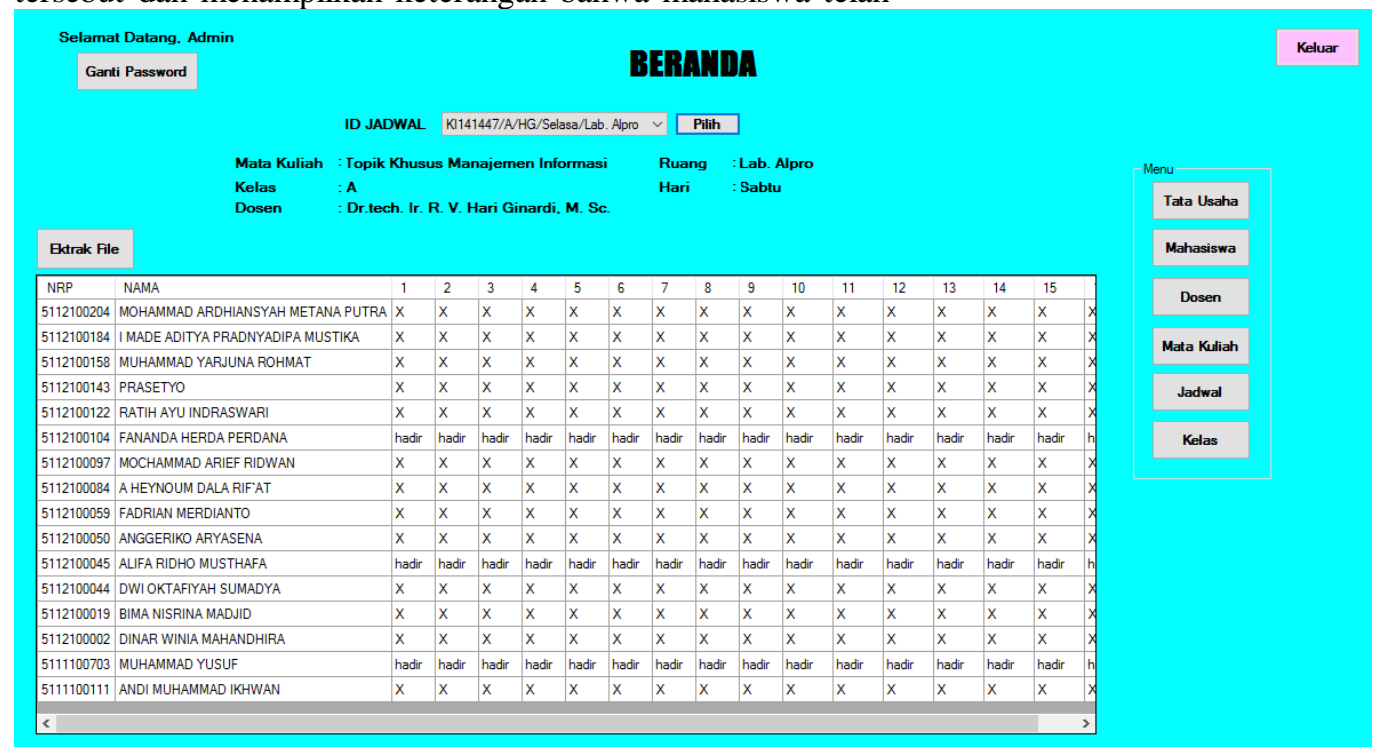

Gambar 5 Rekapitulasi kehadiran per kelas 


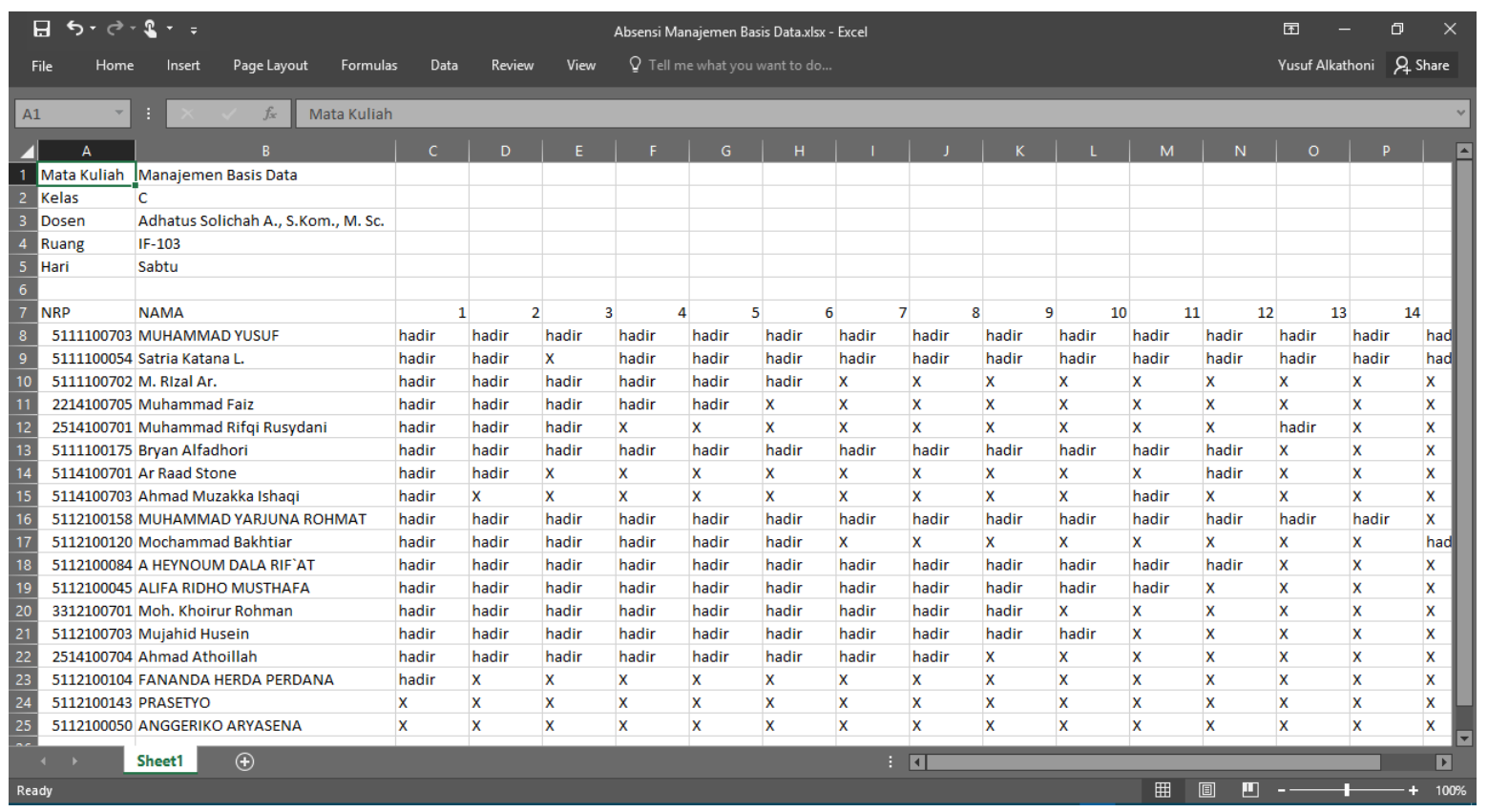

Gambar 6 File data hasil ekstraksi

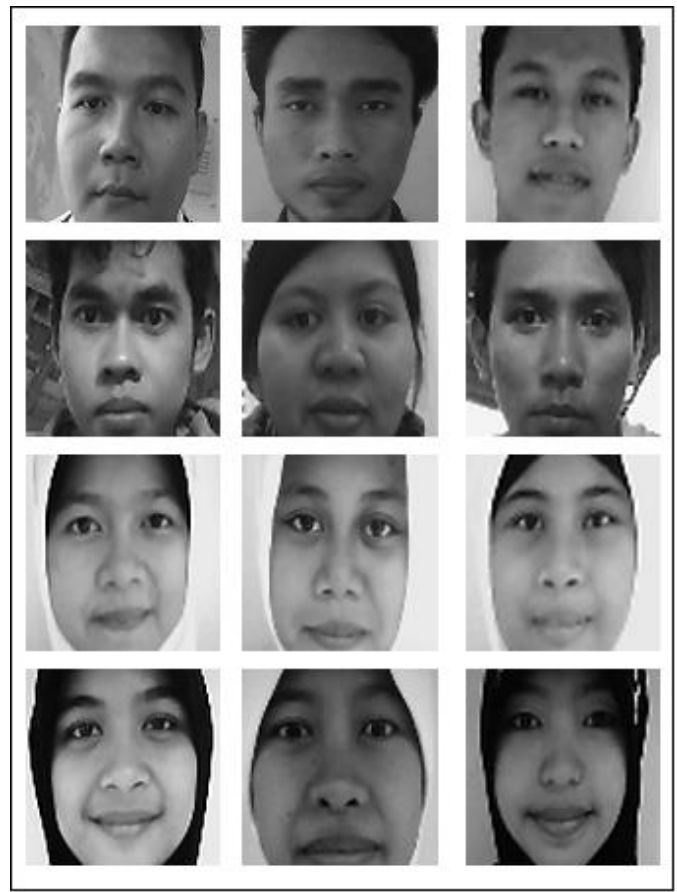

Gambar 7 Contoh dataset wajah yang berhasil dikenali

\section{KESIMPULAN}

Dari hasil selama proses perancangan, implementasi, serta pengujian aplikasi absensi perkuliahan mahasiswa dengan pengenalan wajah, dapat diambil kesimpulan sebagai berikut:

1. Aplikasi berhasil dibangun menggunakan bahasa pemrograman $\mathrm{C \#}$ dengan pengenalan wajah menggunakan library Emgu CV.

2. Metode Eigenface dipanggil dari library Emgu CV yang digunakan pada proses pengenalan wajah mahasiswa untuk mencatat status kehadiran.

3. Rancangan basis data yang digunakan untuk aplikasi ini berhasil dibangun dengan relasional manajemen basis data MySQL yang berisi tabel-tabel login, mahasiswa, foto, dosen, matakuliah, jadwal, kelas, berita acara, dan kehadiran.

4. Aplikasi yang dibangun berhasil mencatat kehadiran mahasiswa pada suatu perkuliahan dengan pengenalan wajah pada kondisi pencahayaan dan resolusi yang sama dengan kondisi foto wajah yang disimpan dalam basis data.

5. Aplikasi yang dibangun berhasil menampilkan data absensi dan mengekstraknya ke dalam file Excel.

6. Aplikasi yang dibangun berhasil melakukan pencatatan data absensi dan perekapan perkuliahan mahasiswa secara otomatis sehingga proses pencatatan dan perekapan perkuliahan mahasiswa lebih efisien.

\section{DAFTAR PUSTAKA}

[1] A. Raj, Real Time Multiple Face Recognition Security System (RTMFS), ResearchGate, 2013.

[2] E. CV, "Emgu CV," 1 May 2016. [Online]. Available: http://www.emgu.com/wiki/index.php/Main_Page. [Accessed 20 May 2016].

[3] H. a. Fatta, in Rekayasa Sistem Pengenalan Wajah, Yogyakarta, Andi, 2009, p. 74.

[4] J. R. d. Solar and N. P., "Eigenspace-based face recognition: a comparative study of different approaches," IEEE Transactions on Systems, Man, and Cybernetics, Part C (Application and Reviews), vol. 35, no. 3, pp. 315-325, 2005.

[5] M. A. T. a. A. P. Pentland, "Face Recognition using Eigenfaces," in IEEE Computer Society Conference, Maui, HI, 1991.

[6] M. R. Muliawan, B. Irawan and Y. Brianorman, "Implementasi Pengenalan Wajah dengan Metode Eigenface pada Sistem Absensi," Jurnal Coding, vol. 03, no. 1, pp. 52-62, 2015.

[7] P. Wagh, R. Thakare, J. Chaudhari and S. Patil, "Attendance System based on Face Recogniiton using Eigenface and PCA Algorithm," IEEE, pp. 303-308, 2015. 